DOI: $10.22559 /$ folklor.1044

folklor/edebiyat, cilt: 25, sayı: 100, 2019/4

\title{
Sedat Veyis Örnek'in Öykülerinde Kadının Görünümü
}

\section{Descriptions of Women in Sedat Veyis Örnek's Stories}

\section{Koray Üstün*}

\section{$\ddot{\mathbf{O z}}$}

Sedat Veyis Örnek (1929-1980), folklor üzerine yaptığı çalışmalarla iz bırakmış bir bilim insanıdır. Örnek, akademik çalışmaların yanı sıra gençlik yıllarından itibaren edebiyatla da ilgilenmiş; lise yıllarında başladığı öykü denemelerini uzun yıllar sürdürmüştür. Bu öykülerde gözlem ve tahlil gücünü yansıtan betimlemeler dikkat çekmektedir. Yazar, gerek olay gerek durum merkezli kurguladığı öykülerinde merkeze insanı alarak yerilen, yüceltilen, zayıflıkları ve güçlülükleriyle farklı perspektiflerden okunabilen anlatıcılar yaratmıştır. Bu anlatıcılar kendi dünyalarını sunarken genellikle kadını bedensel bir meta olarak algılayarak eril bir söylemle bedensel arzu nesnesi olarak tarif etmişler; mekânın anlatıcı üzerindeki izlenimleri sırasında doğan panoramanın bir parçası şeklinde çizmişlerdir. Halkbilimci duyarlılığıyla edindiği izlenimleri, bilimsel çalışmalarının yanı sıra yazınsal faaliyetlerinde de bir kaynak olarak kullanan Sedat Veyis Örnek'in öyküleri kadın kimliği odağa alınarak okunduğunda yazarın, başarılı gözlemlerini kurguladığı eril anlatıcı aracılığıyla sunduğu görülmektedir. Örnek, şehir ve savaş izleklerini barındıran pek çok ögeyi kullanarak kaleme aldığı anlatılarında mekânla birlikte değerini yitiren insanlığı kadın kimliği üzerinden somutlaştırmıştır.

Anahtar sözcükler: Türk öyküsü, Sedat Veyis Örnek, kadın, kadın kimliği, eril anlatıcl

Dr. Öğretim Üyesi, Hacettepe Üniversitesi Edebiyat Fakültesi Türk Dili ve Edebiyatı Bölümü, korayustun@ hacettepe.edu.tr. ORCID ID: 0000-0003-1033- 5966. 


\begin{abstract}
Sedat Veyis Örnek (1929-1980) was a academician who left a mark with his studies on folk. Besides his academic studies, Örnek dealt with literature since his youth. He continued his short stories for many years that he started to write in high school. In these short stories, descriptions reflecting his powerful observation and analysis draw the attention. The author put humans in the middle of his short stories that he wrote both event-focused and situation-focused. Therefore, he created narrators who can be read through different perspectives with their criticized and aggrandized weaknesses and strengths. As they present their own worlds, these narrators perceived women as a physical meta and described them as a physical desire object with a masculine discourse. They pictured women as a part of the panorama emerging from the impressions of the environment on the narrator. Sedat Veyis Örnek who blended his impressions with his folklore sensitivity. Besides his scientific studies, he used his sensitivities as a resource in his literary activities. When his stories have read with focus on the female identity, they have seen that the author presents his successful observations through the masculine narrator. In Örnek's stories about cities and wars, humanity has been lost its value and embodied it through its female identity.
\end{abstract}

Keywords: Turkish short story, Sedat Veyis Örnek, women, female identities, masculine narrator

\title{
Giriş
}

Bir kadın istiyorum

Bir kadin

Anamın sütünden ak olmalı

Bir kadın ki

Bir kutllk senesinde

Taze ekmek kokmalı

(Örnek, 1949)

Sedat Veyis Örnek ${ }^{1}$ (1929-1980), folklor üzerine yaptığı çalışmalarla tanınmışsa da Sivas’ta sürdürdüğü lise yıllarından itibaren edebiyatla iç içe olmuş; gece sekreterliğini yaptığı Hakikat gazetesinde ilk yazınsal ürünlerini yayımlamıştır. Burada öykü, şiir, deneme gibi türlerde eserler veren Örnek, aynı zamanda Sivas Halkevi’nde tiyatro çalışmalarına katılmış, sahneye çıkmıştır. Halkla iç içe yürüttüğü tiyatro faaliyetlerini kaleme aldığı sahne metinleriyle sürdüren Örnek'in Düdük ve Hücum'da yazdığı yazılarla edebiyatla bağını hep koruduğu görülmektedir. Ankara'da sürdürdüğü lisans eğitiminin ardından Kore'de tamamladığı askerliği ve Almanya'da geçen doktora eğitimiyle farklı kültürler ve farklı coğrafyalar tanıma olanağı bulan Örnek, 1947-1965 yılları arasında kaleme aldığı yazınsal metinlerde bu farklılıklardan 
doğan gözlemlerini başarıyla kurgulamış, doğup büyüdüğü topraklardan aldığı ilhamı çağdaş gözlemleriyle harmanlamış ve özgün bir bakışla Türk edebiyatına metin bağlamında da katkı sağlamıştır. Türk öykücülügünün yeni arayışlara girdiği, yeni temalarla zenginleştiği, yazarların hem kendi ülkelerini hem de dünyayı izleyerek hareketli, canlı ve yenilikçi olduğu bir dönemde ${ }^{2}$ eser veren Örnek de diğer yazarlar gibi farklı içerik ve biçemlerle öyküler kaleme almış, geleneksel olay temelli öykülerin yanı sıra farkındalıklarıyla yarı-aydın kimliği gösteren, şehirli bohem insanların duygu ve düşüncelerine odaklanarak kronolojik zaman akışının yerine bütün çıplaklığıyla kurguladığı anlatıcıların belleğini yerleştirmiştir.

Örnek'in öyküleri, çeşitli süreli yayınlarda, farklı periyotlarda yayımlanmasına karşın ortak izlekler taşıyan ve bu nedenle farklı açılardan tasnif edilebilen metinlerdir. Örneğin Arseven, Sedat Veyis Örnek'in öykülerini Almanya öncesi ve sonrası olmak üzere iki başlık halinde ele almıştır (2015: 349). Örnek'in öykülerinin, içerik ve anlatım bakımından tahlil edildiği bu çalışmada, yazarın anlatım ve içerik bakımından zengin bir öykücülüğü olduğu ifade edilmiştir:

Sedat Veyis öykülerinde insana ve yaşama dair pek çok öğeyi tartışmaya açar. Gurbet, ölüm, yalnızlık, yoksulluk, insan sevgisi ve özlem bunlardan bazılarıdır. Yazarın daha önce yayımlanan öykülerine göre son dönem yazdıkları gerek konuyu işleyişi gerekse teknik özellikleri bakımından daha iyidir. İçerik ve şekil yönünden öykülerde bir birlik bulunmamaktadır Sedat Veyis'in, kahraman anlatıcı bakış açısını seçmiş olması, yazar ile kahramanı arasında kurulan ilgiyi güçlendirmektedir. Öyküler bütün olarak ele alındığında hepsinin özünde ayn olduğu görülmektedir. Bu özde yaşam ve yaşam içinde bir şekilde hırpalanmış, kimi zaman inancından, kimi zaman yaşamından, kimi zaman kendinden vazgeçmiş bireyin açmazları vardır. Sadece mekânlar, kişiler ve istekler şekil değiştirmektedir (Arseven, 2015: 365).

Örnek'in öykülerinde mekânın anlatıcı üzerinde etkisi büyüktür.3 Mekânlarda görülen değişimler, kişi ve olay üzerinde de farklılıkları doğurmuştur. Bu nedenle yazarın Türkiye ve yurtdışı gözlemlerinin iki ayrı kaynak olarak öykülerinde yer ettiğini söylemek mümkündür. Anadolu' da geçen öyküler toplumsal gerçekçiliğin izlerini taşıyan ve daha çok köyün ve köylünün günlük yaşamındaki değişimler üzerine odaklanırken Kore ve Almanya'da bulunduğu dönemdeki gözlemlerinin izlerini taşıyan öykülerinde olaydan çok durum ağırlık kazanmış; anlatıcının düşünceleri öyküye dönüştürülmüştür. Yazarın taşra anlatılarında erkek merkezli toplumun sesi anlatıcıya dönüşürken şehirlerin mekân olarak kurgulandığı metinlerde kadın kahramanların da yer aldığı ve bu kadınların anlatıcının belleğinde yer eden bir imaj olarak aktarıldığı görülmektedir. Bu bağlamda Örnek'in öykülerinde toplumsal cinsiyete dayalı söylemin izlerini görmek mümkündür. Toplumsal ve kültürel değer yargılarıyla inşa edilen toplumsal cinsiyet, biyolojik cinsiyetin doğallığ ve değişmezliğinin aksine insan eliyle oluşturulmuş; değişen bağlamlarla göre farklılıklar göstererek zaman içerisinde yeni roller, görevler ve kimliklerin doğuşuna tanıklık etmiştir. Toplum odaklı bir edebiyat okumasında da algının dile yansıması sonucu somutlaşan cinsiyet örneklerini tespit etmek mümkündür ${ }^{4}$. Sert, bağımsız ve cesur mitsel erkekliğin tam karşısına itaatkâr, sevecen ve çok güzel bir kadın konumlandırılmıştır. Bu roller, erkekliğin alanını sosyal anlamda sınırsızlaştırırken kadını bir fanus içerisinde varlık göstermeye itmiştir. Yazınsal bağlamda dil aracılığıyla gerçekleşen bu rol dağılımında eril anlatıcı rol dağılımı görevini üstlenerek belleğindeki rolleri 
dile dökerek kadını beden-ruh ikiliğinde kurgulayarak kendi arzularına göre bedensiz bir ruh ya da ruhsuz bir beden olarak görmüştür. Örnek'in öykülerinde karşımıza çıkan eril bakış açısında da bu tavrın benimsendiği, anlatıcının kendini bir yandan kadında aradığını diğer yandan da ısrarla kadını yok sayarak metalaştırdığını söylemek mümkündür.

\section{Eril anlatıcının belleğinde ve izlenimlerinde metalaşan "Ruhsuz Bedenler"}

Sedat Veyis Örnek'in öyküleri, olaydan çok durum üzerine kurgulandığg için anlatıcının sesi çoğu zaman betimleme ve tahlillerin önüne geçmektedir. Bu nedenle öykülerde yer alan kişilerin tümü anlatıcının konumlandırdığı noktaya göre anlatıdaki yerlerini edinmektedir. Anlatıcının kendini yakın hissettiğini, bir duygu bağı kurduğu kişiler öykülerde detaylandırılırken mekân, zaman ya da bir başka kişi ile ilişkilendirilerek bir fon içerisine yerleştirilmiş kişiler silik ve tek yönlüdür. Bu bağlamda öykülerdeki kadınların varlığı da anlatıcıyla olan bağlarıyla ilişkilidir. Öykülerdeki hâkim erkek sesi kadını, belleğinde ve izlenimlerinde yer ettiği kadar sunmuştur. Bedene hapsedilerek cinsel boyutlarıyla varlık gösteren silik portrelerden ibaret bu kadınlar; kültürel, sosyal ya da politik hiçbir varlık göstermemekte, ekonomik varlıklarını bedenleri aracılığıyla idame ettirmektelerdir.

Örnek'in yayımlanan yirmi dört öyküsünün on yedisinde kadın bedensel varlığıyla kendini göstermektedir. Yazarın öyküleri arasında kadınların göründüğü öyküler şunlardır: Bir Kahpeden Ne Beklenir?, Gece Yarısından Sonra, Günahkârlara Dair, Mezarlıktan Bir Kaçıs,, Park, Illonka, Saat Dördü Bilir misin?, Yelpaze, Bir Şehirden Üç Kişi, Kuzey-Güney, Acı Bal, Cam Önünde, İlonka'ya Mektup, Sabah, Suda Oynar Balıklar, Köpekli Kadın ve Tabut. Yazarın Bir Kahpeden Ne Beklenir? Yelpaze, İlonka'ya Mektup ve Köpekli Kadın adlı öykülerinde kadın bir kahraman olarak karşımıza çıkarken diğer öykülerde belleksel ya da mekâna dayalı anlatıcı betimlemelerinin bir parçası olarak görülmektedir.

Yazarın Bir Kahpeden Ne Beklenir? adlı öyküsü, askere gidecek Yaşar'ın dönüşünde sevgilisi Zehra'yı bulamamasını konu edinmekle birlikte esas olarak askere giden sevgilisine sadık kalmayan, çıkarcı ve bedensel kimliğiyle toplumda yer edinmiş bir kadının durumunu ele alan bir öyküdür. Bu öyküde bir kadın-erkek ilişkisinden doğan olayların anlatımından çok kadına ve erkeğe yüklenen cinsiyete bağlı rollerin doğurduğu durum anlatılmaktadır. Yaşar; keskin suratlı, kavruk yüzlü, seksen kiloluk tayfayı kaldırıp denize atabilecek kadar güçlü, eli balyoz gibi bir erkektir. Çizilen erkek profilinde hâkim söylem güç odağına alınmışken Yaşar'la üç aydır birlikte olan Zehra, dişilik vasıfları üzerinden çizilmiştir. O, "İstep gecelerine benzeyen" gözleri şehvetten alev alev yanarken kırmızı dudaklarıyla "ne yosma ne civelek"tir (2015:630). Anlatıcı fiziki özelliklerinden hareketle karakter özelliklerini tasvir etmiş; Yaşar'ın imajından nasıl bir erkek çıkarmışsa Zehra'dan da fiziksel görünümden hareketle aynı şekilde bir "hafif meşrep" yaratmıştır:

Yaşar'ın, bu keskin suratl, kavruk yüzlü cenup çocuğunun kuvvetli kolları vardl. Urus (Rus) Halit'in kahvesinde bir tayfayı kavradı̆̆ınnan penceresinden denize firlatmıştı. Seksen kiloyu yüklenir de bana misın demezdi. Dile kolay be! Seksen kilo. Ne de yüzerdi ya. Motor gibiydi motor. Yalan yok sık da yumruk atardı. Nasirl hantal eli yumulduğunda balyoz gibi olurdu. Herifte latura vardı. Boru değil! Zehra'nın gözleri mi? Sorma be anam! Istep gecelerine benzerdi istep. Şehvet alev 
alev yanardı gözlerinde. Kırmızı dudakları iştihadan sıcaktan yarık yarıktı. Çiçekli basmasının sarmaladı̆̆ vücudu ne hoştu. Zehra'nın biricik zevki Yaşar'ın kolları arasında çırpınmak solumak ve pörsümekti. Ve Yaşar kaç kere onu kavralamış dudaklarını kaç kere kanatırcasına öpmüştü (2015: 630).

Kahramanların mesleklerine dair yer alan ifadelerde de bu cinsiyete dayalı karakter çizimi belirginleşmektedir. Yaşar, hırsızlık ya da hamallık yaparken Zehra "başkalarına da cömert davranıp para kazanmaktadır” (2015: 639). Yaşar'ın askerlik dönüşü Zehra'yı bulamaması ve Zehra'nın bir tayfaya kaçtığı haberini alması öykünün başından beri hissettirilen geçici duygu durumunun bir görünümü gibidir. Kadın, sevdiğine bağlı kalmamış ve onu askerdeyken terk etmiştir; erkek ise bu durumu önemsemeden yaşamını sürdürmüştür.

Örnek'in bu öyküde çizdiği Zehra, yazarın diğer öykülerinde de karşımıza çıkacak hayat kadını tipinin bir örneğidir. Burada en dikkati çeken husus, Zehra'nın “cenup kadını kadar cömert” olarak tanıtılmasıdır. Anlatıcı, Zehra'nın bütün cesur davranışlarını onun "cenup kadını" olmasına bağlamıştır. Yazar, çizdiği diğer hayat kadınları gibi Zehra'yı da taşradan uzaklaştırarak güneye, denize, kendi ait olduğu coğrafyadan bir başka noktaya yerleştirmiştir. Örnek'in bu öyküsünde belirgin olan erkeğin kadını algılamasında cinsiyete dayalı imajların ana etken olması, yazarın diğer öykülerinde de kendini göstermektedir.

Kuzey Güney adlı öyküde anlatıcının seslendiği kişi için kadın bedeni, bir metadır. Günün sıradan akışı içerisinde olağanlaştırılmış rutinlerden biri de kadın bedenini düşünmek ya da hissetmektir. "Bir göl durgunluğu içinde günü takvime eklerken bir taş, bilinmez bir taş yaşamanı bulandırır. Sen kirli kadınların, kıvamsız sigaraların, ilk bakışta tanıdığın mektupların, akşamüzerleri gelen bir efkârın, bazen tek sütuna verilmiş şapkalı bir gazete haberinin, diline pelesenk ettiğin bir Zara türküsünün içine uzanıp yaşarsın. Sürüp gider işte... (2015: 660)" cümleleriyle yaşanan amaçsız ve boşa geçen ömürde kadın, herhangi bir duygu bağı kurulmadan yalnızca bedensel tatmini sağlamak için hayata dâhil edilmiş bir nesne gibidir. Bir askere hitaben yazıldığı anlaşılan öyküdeki diğer kadın tipi ise sırtında bir çocukla görünen savaşın ortasında varlığını sürdürmeye çalışan annedir. Buradaki kadın önce savaşın yarattığı dramatik ortamın bir parçası gibi iken ardından akşamın olmasıyla birlikte cinsel arzularının uyanması sonucunda dişiliği ile ön plana çıkan bir kadına dönüşmüştür.

Örnek, pek çok öyküsünde şehrin panoraması içerisine yalnızca cinsel varlığıyla görünen kadını yerleştirmiştir. Suda Oynar Balıklar'da da bu imaj karşımıza çıkmaktadır. Öyküde anlatıcı, bir köşede öpüşen bir çift görmüş ve kızı eski sevdiğine benzetmiş ve onun "Sakal bırakırsan sana bir öpücük veririm” (2015: 670) deyişini anımsamıştır. Yine şehri, insanları ve rutiniyle betimlerken kadınları da bu tabloya yerleştirmiştir. Sokakta "gecenin içinde küçük orospulara, sarhoş Fas'lı askerlere, ürkek Japon öğrencilerine” (2015: 670) rastlayan anlatıcı, tarif ettiği sokaktan geçerken rastladığı bazı kadınları şu cümlelerle aktarmıştır: "Bazı akşamlar bu sokaktan geçerken, pencerelerden dışarı sarkmış gürbüz, anaç, şehvetli kadınlar görürdü. Çoğu kez aklından, bu kadınlardan birisiyle serin ve aydınlık bir odada yatmayı, sonra da ölmeyi geçirirdi. Hintli kimya öğrencisi bu sokakta oturuyordu. Hârikulâde güzel gözleri vardı" (2015: 671). Bu bağlamda kurgulanan öykülerde yer alan kadınlar; erkek kahramanların içinde bulundukları psikolojik boşlukları doldurmak için hayal edip sığındıkları, cansız bir nesne gibidir. 
Yazarın Almanya izlenimlerinden doğan Cam Önünde adlı öyküsünde ise anlatıcının gözlemlediği kadınları nasıl betimlediğini okumak mümkündür. Bu kadınlardan ilki anlatıcının oturduğu kafeye erkek arkadaşıyla gelen bir kadındır. Anlatıcı, bu kadının dış görünüşünü “...oturdular. Erkek şarap söyledi, kadın sütlü kako. Kadının geniş ve aydınlık alnını daha da anlamlı kılan iri camlı, kalın çerçeveli gözlüğü vardı. Sırtına hafta sonlarında dağ otellerinde giyilen dik yakalı, bol döküm sarı bir kazak geçirmişti. Gözlüğünü bir çıkartsa! Camlarını hohlayıp, temizlese! Görsem gözlerini! Sabah kırağında buğulu iki üzüm mü?” (2015: 663) cümleleriyle betimledikten sonra kafedeki bir diğer kadını tanıtmaya başlar:

Büfenin önünde kısa boylu, saçları ensesini döğen, uzun favorili, yarı Maksim Gorki bıyıklı Italyan işçisi ile oturan kız, deminden beri fikırdayıp duruyor. Tanıyorum. Vitrininde, kıçlarına kağıttan yapma çiçekler sokulmuş domuzlar bulunan kasap dükkânında çalışlyor. İşi gücü işçilerle, kente henüz yeni düşmüş acemi yabancılarla çıkmak. Diri ve arsız kalçasını kaşe bir etekliğin içine zor sı̆̆dırmış (2015: 663).

Bu tasvirlerin ardından kafeden ayrılarak şehrin sokaklarına kendini bırakır. Sokakta fahişelere denk gelir. Anlatıcının bahsettiği kadınların ortak noktası bir flört halinde olmalarıdır. Aylak bir adamın şehir izlenimlerinden oluşan metinde kadın, şehir panoramasında figüratif bir nesne gibidir. Sığlaşan eril bir bakışla kadın yalnızca bedeniyle hayatta kalabilen bir metadır.

Mezarlıktan Bir Kaçış adlı öyküde kadın, şehir ve yaşamla ilişkilendirilen bir nesne durumundadır. Yazar, bu öyküsünde de kadın figürünü canlı bir betimleme ile sunmamış; anlatıcının belleğinde yer ettiği cinsel arzu nesnesi olarak yer edişi ile yalnızca anılmıştır. Şehrin "boyalı kadınlarından" kaçan anlatıcı, kendini bir mezarda bulur. Rasgele bir mezarın başında durur. Anlatıcı, mezarlıkta kabir sahiplerinin yaşarlarken kadınlarla olan ilişkilerini düşünür. Örneğin Aptullah isimli medfun hakkında "Belki karanlık bir sokakta bir frengili kadını zorla öptüğü olmuştur” (2015: 637) diye kendi kendine söylenir.

Bu Şehrin İçinden: Günahkârlara Dair adlı anlatıda da düşmüş bir kadının anlatıcının belleğindeki görünümü aktarılmaktadır. Anlatıcı (yazar) gece oturduğu yazıhanede düşünürken aklına "hayatta tek başına kalmış, geçimini karanlık sokaklarda arayan, mukaddesatına pervasızca küfreden kadınlar” gelir. Bu kadınlardan birini çok küçük yaşta tanımıştır. Kadının içinde bulunduğu durumu sorgulayan anlatıcı, onun "düşmüş" olmasının toplum tarafindan kendi suçu olarak tanımlanmasını tartışmakta, bu durumun sorumlusu olarak tüm toplumu görmektedir:
Düşmüştü işte. O düştüyse bize ne sanki? Kör mü düşmeseydi! Işste bunu söylüye- biliyoruz. Utanmadan, yüzümüz kızarmadan bunu söylüyoruz. Sanki o başka bir iklimin çocuğu. Sanki o bizden değil. Sanki bizim hiç bir günahımız yok. Şu, gözleri alabildiğine aç, sabah sabah kime kazık atacă̆ım diye firıl firıl dolaşan simsar, şu köşe de pinekliyen hamal, otomobilinden lütfen inen efendi, gözünün dibindeki ha- kikatı görmeyip de mevzuunu ta ötelerde arayan kör muharrir, şapkasının vizyeri yana yıkılmış serseri, duglas bıyıklı miras yedi, iri göbekli tüccar, hepsi bu işten mesul! (2015: 634).

Anlatıcının diğer anlatılardan farklı olarak burada düşmüş kadını, bir cinsel imaj olmaktan çok toplumsal problemlerin bir sonucu olarak görmesi dikkate değerdir. Kadının içinde bulunduğu durumun nedeninin erkeklerde aranması ve pek çok farklı meslek/statü grupla- 
rından erkeğin bu durumun paydaşı olarak aktarılması, anlatıcının öykü kişisi kimliğinden sıyrılarak yazar kimliğini üstlenmesinden kaynaklıdır. Anlatıda olay ya da durumdan düşünceye kayılmış, bir farkındalık çağrısına yaklaşılmıştır. Yazarın kadının şu anki durumunu açıklarken kurduğu "kız, bir porsuyon fasulye yemeği için kim bilir kimin kahrını çekiyor" cümlesiyle bedenini satmak zorunda kalan kadınların maddi yetersizliklerden dolayı bu durumda oldukları ifade edilmek istenmiştir.

Örnek'in kadının cinsiyet bağlamındaki toplumsal konumunu irdelediği öykülerinden biri Yelpaze'dir. Yazarın savaş nedeniyle Kore'de bulunduğu dönemde yaşadıkları ve gözlemlediklerinden izler taşıyan bu öykü, savaş ortamında kadınların toplumsal konumunun ne denli değiştiğini, ekonomik varlıklarını sürdürebilmek adına bedenini satmak zorunda kalmalarını işlemektedir ${ }^{5}$. Öyküde, Koreli bir hayat kadınının hastalanan çocuğunu iyileştirme çabasındaki bir askerin, bu çabadan vazgeçerek taburuna dönüp kadını ve çocuğunu unutmasına rağmen kadının askerleri uğurlarken o askerin içinde bulunduğu araca çocuğunu iyileştirmesinin karşılığı olarak askerin çocuğu iyileştirmek için kullandığ yelpazeyi atmasının anlatıldığı öyküde, anlatıcı bu kadını anneliği ve mesleği ile arasındaki çelişkiden hareketle işlemektedir. Bu kadın, "gecenin içindeki yapışkan, pis, üretrit mikrobu taşıyan aç kadınlardan” biridir. Anlatıcının sefil bir tablo içerisine yerleştirdiği bu kadın, askerler için akşamla gelen yalnızlığın tek çaresidir. Kadının bedeninin metalaştığı bu perspektifi kıran ise hasta olan kızı için askerleri doktor çağırma konusundaki ikna çabasında kendini göstermektedir. Anlatıcı, natüralist bir tavırla kadının içinde bulunduğu durumun nedenini açıklayarak anlatmaya başlamış; savaşta ölen kocasının ardından zenci bir asker tarafından tecavüze uğramasının ardından farklı milletlerden pek çok asker avucuna sıkıştırdıkları para karşılığında kadınla birlikte olmuşlardır. Kadın sonunda bu durumu yadsımaya başlamış ve hayatta kalabilmek için bu yoldan çıkamamıştır. Çocuğunu sigara dumanından girilmeyen kirli ve kokulu odasında büyütmeye çalışan kadının askerleri uğurlarken yüzündeki aydınlık gülümsemenin nedeni ise çocuğunun iyileşmesidir. Anlatıcı, kadın kimliğini yine cinsellik ve annelik kavramları arasında sıkıştırmış ve kadını erkeğin bakışından tanımlamıştır.

Örnek'in öykülerinde, bedensel arzu nesnesi olarak yer bulan kadınlar, eril bakışın toplumsal cinsiyet bağlamındaki kalıp yargılarının izlerini taşımaktadır. Tek yönlü olarak betimlenen ve anlatıda yer eden bu kadınlar, erkek anlatıcının cinsel dürtülerinin uyanışında metalaşmışlar; ekonomik ya da duygusal hiçbir üretimin içerisine konumlandırılmamışlar, mesleki herhangi bir rol üstlenmedikleri gibi duygusal hiçbir reaksiyona da girmemişlerdir. Fiziksel ve psikolojik betimlemelerinin görülmediği kadınlar, eril sesin dünyasında edilgen ve bedeni üzerinden kendine yüklenen rolü kabullenmişlerdir. Yazarın Almanya ve Kore'deki günlerinden izleri ${ }^{6}$ taşıyan bu öyküler, anlatıcının içinde bulunduğu sistemin yarattığı boşluk hissini kadını bedensel bir arzu nesnesi olarak görerek doldurma çabasını anlatmaktadır.

\section{Görülmeyen, hissedilen “Bedensiz Ruh”: Illonka}

Örnek'in İlonka isimli kadına yazılan mektuplar şeklinde kurguladığı öyküleri, Illonka, İlonka Saat Dördü Bilir misin? ve İlonka'ya Mektup'ta diğer öykülerindeki kadın imajından çok daha farklı bir kadın kurgulanmıştır. İlonka, Örnek'in kaleminde idealleştirilmiş/özlenen sevgilidir. Anlatıcının kaleminde uzağa konumlandırılmış bu kadın saf, hayal ve uzakken 
yakınındaki, gördüğü, “gerçek kadınlar” bedenlerini pazarlayan, cinsel varlıklarının dışında toplumun hiçbir katmanında yer bulmayan metalardır. Bu öykülerde kadın kimliği masumiyet-kirlenmişlik ikiliği üzerine kurulmuş gibidir; İlonka, yaşamamış kadar temizken diğer kadınlar bütün saf güzelliklerine rağmen kirlidir.

Anlatıcı ilk öykü Illonka'da seslendiği kadın ile aralarındaki uzun mesafeyi "tam 78317 metre uzaktayım. 12 metre yüksekteyim ve hislon marka saatım senin hiçte hoşuma gitmeyen saatından ileri” (2015: 635) cümlesi ile aktarmış, sayısal verilerle fiziki yoksunluğu somutlaştırmasının ardından İlonka’nın hayal güzelliğini günlük ritüellerini sıralayarak gerçeğe dönüştürmüştür. İlonka; piyasa romanları okuyan, sinemada akşam seanslarına giren ve orada yanına oturan tanımadığ 1 erkeklerle bakışan bir kadındır. Yaşamın varlığına işaret eden bu betimlemelerde anlatıcının İlonka'yı metalaştırmayarak diğer anlatılardakinden farklı bir kadın figürünü aktardığı görülmektedir. İlonka, realitede yoktur ancak anımsattıkları ve bıraktığı izlenimlerle canlıdır. Bu nedenle yaşayan, var olan ancak düşmüşlükleriyle anlatıcıyla psikolojik yakınlığı bulunmayan bütün kadınların tam karşısında bir noktaya konumlandırılmıştır. İlonka'nın dışındaki diğer kadınlar, anlatıcı tarafından tanınmamakla birlikte anlatıcıya kendilerini fark ettiren, İlonka'dan düşük kimselerdir. Köprüden geçerken eteği havalanarak anlatıcının aklına "kötü şeyler" getiren baytarın karısı, altı yedi yıl evvel kaymakamın oğlunun adını ağaca kazımasının ardından koruluğa götürdüğü genç kız, akşamüstleri gezmeye çıkan ve hep siyah giymesinden ötürü anlatıcıda yas tuttuğu izlenimi uyandıran gizemli kadın ve anlatıcıya çirkin olduğunu acımadan yüzüne söyleyen şarkıcı kadın öyküde çağrışım yoluyla aktarılan ve İlonka'nın aşkla kutsanan varlığının tam karşısına konumlandırılmış kadınlardır. Anlatıcı, İlonka’nın güzelliğinden bahsederken dahi başka kadınlarla karşılaştırma yapar:

Zaten senin en çok saçlarını severim. Şöyle mısır püskülü gibi, kadife gibi yumuşak yumuşaktı değil mi? Köylü kızlarının da saçları güzeldir. Üç dört örgü halinde ta kalçalarına kadar sarkar. Ama onlarınki yağlıdır kirlidir, sirkelidir (2015: 635).

Anlatıcının bu tavrı, İlonka’nın bütün sıradanlığına karşın anlatıcıda yarattığı hayranlığın bir işaretidir.

İlonka’ya hitaben yazılan bir diğer öykü Bir Mektup: İlonka, Saat Dördü Bilir misin? de ise anlatıcı bu kez zamanı irdeleyerek anlatısını başlatır. Sabaha karşı saat dörtte, yine bir iç monoloğu çağrıştıran üslubuyla İlonka'ya seslenen anlatıcı, rüya ile düşünce arasında bir bağ kurmuş; İlonka'yı "çiçek çiçek rüyaların içinde” bırakırken kendi şehrin insanlarını düşünmeye başlamıştır. Anlatıcı, yine İlonka’yı hayal dünyasında yüceltirken realitenin sertliğiyle karşı karşıyadır. Kumral saçlarını çelik makinelere kaptıran insanları, fahişeleri, verem kliniğinde yatan hastaları düşünür ve bütün bu kimselerin gecenin karanlığıyla bütünleştiğini ifade eder. Gecenin içerisine yerleştirilen bu realite İlonka'ya hayli uzaktır ve anlatıcı bu gerçeklikten İlonka'yı haberdar etmek ister:

Şehrin varoşlarında gözleri karanlık, elleri karanlık, saçları karanlık, bu karanlık saatte düşünceleri daha karanlık kimseler ya vardır, ya yoktur.

Alın yazılarıyla hür, alın yazılarılla çırılçıplak orospular bile toprakla toprak, ışıkla ışılktırlar bu saatte!.. 
Ve sen bilir misin İlonka, şehrin kuzeyindeki verem pavyonunda yatan hastalar taburcu kelimesini sarı gözkapaklarıyla sımsıkı kapamışlardır.

Ve sen bilir misin Illonka, beton arma hapishane dört yüz on sekiz mahkûm, dört yüz on sekiz duvar halinde muhayyilelerinin etrafinı sınırlamışlar, affı rüyalarının iklimine bile sokmazlar.

Biz bu saatta huzurumuzu kaybettik (2015: 640).

Anlatıcı, hayal-gerçek çatışması içerisinde kendi bunalımına dönerek içinde bulunduğu psikolojiyi İlonka’ya anlatmak istemiş; gerçek insanlarının varlığından gecenin yarattığı ürpertiyle huzurunu kaybedişini ifade etmiştir.

İlonka’ya hitaben yazılan İlonka'ya Mektup adlı son öyküde ise İlonka'nın geçmiş ve an içindeki tasviri yapılmıştır. Temizlik ve kirlilik ikiliğinde 'ölü’ İlonka, yine masumiyetin temsili iken bütün saf güzelliklerine rağmen şehrin diğer kadınları kirlenmişler cephesindedir. İlonka'nın beyaz bir hastanede odasında, ateşler içerisinde yatarken ölümünü hissedercesine susmasını anımsayan anlatıcı, ona "uçuk mavi gözlerini hayretle açıp, bir yerlerde Mozart'1n Küçük Gece Müziğini çalarlarken öleceğini biliyor muydun?” diye sorarak bir ölünün arkasından bu satırları yazdığını hissettirmiş ve şimdiye değin güzelliğiyle idealleştirdiği İlonka'nın ölümünü sert bir gerçeklikle tasvir etmiştir:

Gözlerinin duru mavisini kara böcekler çoktan yemiştir, şimdi. Saçların ot olmuştur sarl-yeşil. Kalbin yağmurlar altında ıpıslak. Ellerini, bir çift beyaz güvercin ellerini iki yanına koymuşlardı. On parmağın on küçük zambaktı, soğuk. Beyaz geceliğinin fiyongu yana kaymıştı. Küçük masanın üzerinde vitaminlerin, ilaçların, saç tokaların, kol saatın, not defterin vardı. Sonra cevabı yazılmamış bir mektup (2015: 665).

Bir intihar sahnesini anımsatan bu betimlemenin ardından anlatıcı, İlonka'nın ölmeden önceki günlük yaşamını tasvir etmeye başlamıştır. Geceye karşı ışıklarını yakan şehrin büyük caddelerinden birindeki bir kitapçı vitrininde Heinrich Böll romanına gözlerini diken İlonka, her zamanki gibi yeşil trençkotunu giymiş, saçlarını sıkıca firçalamış ve ensesinde toplamıştır. Bu tasvirin peşinden anlatıcının İlonka'nın "yanından hızla geçerken, onu duymaması ve onu bilmemesinin” aktarması, karşılığı olmayan bir aşkın işaretidir. Ölümle birlikte anlatıcı, şehrin günlük eğlencesine kendine bırakmıştır ancak İlonka'sız her şey yok hükmündedir:

Sonra ben kahvelere, balolara, faşinglere gidiyordum. Kahveler, faşingler, danslar senin ölümünle çirkindi artık. Her şey bir sıkıntı çizgisinden başlıyor, bir çirkinlik karanlığında bitiyordu. Kızlar, sen olmayan kızlar, ateşleri normal, uykuları iyi, sıhhatli kızlar önce gülüşlerini, sonra dudaklarını veriyorlardı. İki öpüş arası ağulu çiçekler boy atıyordu bir kötü karanlikta! (2015: 665).

Öyküde, fahişeler yine şehrin bir parçası olarak sunulurken kadına anlatıcının bunalımını giderme işlevi yüklenmiştir. Anlatıcı için kadın bedeni, ihtiyaç duyduğu terapinin bir parçası gibidir.

İlonka'ya hitaben yazılan mektuplar şeklinde kurgulanan bu öyküler, kadını arzu nesnesi olmaktan sıyırarak karakterinden alışkanlıklarına kadar detaylı betimlemelerle yazarın diğer öykülerinden ayrılmaktadır. İlonka; okuma alışkanlıkları, beğenileri, endişeleri, defterleri 
gibi pek çok öge aracılığıyla karaktere dönüştürülmüş ve anlatıcı, İlonka'yı farklı cephelerden sunarak kutsal kadın imajıyla harmanlanmış bir kadın tipi çizmiştir.

\section{Hayvansever Kadınlar}

Örnek'in şehir odaklı anlatılarından olan Bir Şehirden Üç Kişi ve Köpekli Kadın öykülerindeki iki kadının ortak yönü hayvansever olmalarıdır. Anlatıcının algılamakta zorlandığı bir hayvan sevgisini barındıran bu kadınlar, cinsellik ve aşk bağlamından çok anlatıcının zihninde sorguladığg bir sevgi üzerine kurgulanmışlardır.

Bir Şehirden $\ddot{U} c ̧$ Kişi adlı öyküde anlatılan üç kişiden biri kedi seven kızdır. Bir parkta "açlıktan ve soğuktan suratı uzamış, sevimsiz, rezili rüsva" (2015: 659) olan kediyi seven kızla konuşmaya başlayan anlatıcı, kızın kediyi sevmemesini söyler ve anlaşılmadık bir biçimde tehditkâr bir üslupla kediyi hemen bırakmasını ister. Kız kediyi bırakmak istemez ve anlatıcıya yaklaşarak onu alnından öper. Anlatıcı, anlatının sonunda bu kızı parkın kuytu bir yerine götürür. Kedi ile kendi arasındaki bağı kedi seven kızın şefkatinden hareketle kuran anlatıcı, öykünün sonunda tepelerinde duran kediyi savuşturarak rakibini uzaklaştırmak ister gibidir. Burada da kadın kimliğinin şefkat ve cinsellik bağlamında işlendiği görülmektedir.

Örnek'in hayvan sevgisi ile ilişkilendirerek öyküleştirdiği bir diğer kadın, Köpekli Kadın adlı öyküsünde karşımıza çıkmaktadır. Kalabalık bir lokantada masa bulunmadığından ötürü masanın altından köpeğini besleyen bir kadınla aynı masada oturmak zorunda kalan anlatıcı, bu kadınla konuşmalarını aktarmış; diyaloglar aracılığıyla kadının geçmişi ve davranışlarını sunmuştur. Pahalı bir çikolatayla köpeğini besleyen kadın, lokantada hayvan beslenilmesine izin verilmediği için anlatıcının yemediği balığı köpeğine vermek istemiş ancak anlatıcı hayvan sevmediğini söyleyerek yememesine rağmen tabağındakileri onunla paylaşmamıştır. Kadın, köpeğine olan sevgisini anlattıkça, anlatıcı onunla alay eder bir tavırla kendinin de hayvan sevgisinin olduğunu, atları ve balıkları sevdiğini söylemiştir. Bir kere evlenen ancak kocasının köpekleri sevmediğinden dolayı evliliğinin üçüncü günü boşandığını anlatan kadın, evindeki yavrulardan birini anlatıcıya vermek istemiş fakat olumsuz bir yanıt almıştır.

Anlatıcı, bu şehirli kadınların hayvanlar için sarf ettikleri çabayı ve özveriyi anlamamakta hatta onları hakir görmektedir. Bu düşünceden dolayı hem hayvanlara hem de kadınlara karşı alaycı bir tavır takınarak şehirli kadının evcil hayvanlarla bağını tartışır gibidir.

\section{Sonuç}

Sedat Veyis Örnek'in 1947 'den itibaren kaleme aldığı yirmi dört öykü bulunmaktadır. Yazarın mekân ve insan bağlamında kurguladığı bu öykülerde kadınların görünümünde belirli ortaklıklar göze çarpmaktadır. Özellikle durum öyküsü olarak adlandırılabilecek parçalarda anlatıcılar, kadını cinsel bir meta olarak şehir, savaş, geçmiş gibi pek çok izlekle ilişkilendirerek ele almış; kadın, bedensel bir arzu nesnesi olarak çizilmiştir. Yazarın Anadolu’yu işlediği öykülerinde kadına neredeyse hiç yer verilmezken şehir merkezli anlatılarında kadının varlığı söz konusudur. Ancak bu kadınlar, karaktere dönüşmeyen, erkeğin günlük yaşamı içerisindeki belleklerinde kurguladıkları cinsel iktidar alanlarında görülen ve bedensel bir formdan ibaret gibi çizilen kadınlar olup tamamen eril bir söylemle aktarılan ve bu bakışın gördügü kadarından ibarettir. Yazarın kaleminde bu imajdan sıyrılarak çok yönlü bir imaj barındıran tek kadın İlonka'dır. İlonka’ya hitaben yazılmış mektup formundaki üç ayrı öyküde bayağılaştırılan 
kadın kimliğinin yerini hayranlık uyandıran bir kadın çizilmiştir. Günlük yaşamı, beğenileri, alışkanlıklarıyla, gerçek-hayal çatışması içerisinde kurgulanmış olan İlonka, masum ve saftır.

Halkbilimci duyarlılığıyla edindiği izlenimleri, bilimsel çalışmalarının yanı sıra yazınsal faaliyetlerinde de bir kaynak olarak kullanan Sedat Veyis Örnek'in öyküleri kadın kimliği odağa alınarak okunduğunda yazarın, başarılı gözlemlerini kurguladığı eril anlatıcı aracılığıyla sunduğu görülmektedir. Örnek, şehir ve savaş izleklerini barındıran pek çok ögeyi kullanarak kaleme aldığı anlatılarında mekânla birlikte değerini yitiren insanlığg kadın kimliği üzerinden somutlaştırmıştır.

\section{Notlar}

1 Örnek'in detaylı yaşamöyküsü için bkz. Aygün Cengiz vd. 2017.

2 1940-1960 arası Türk öykücülüğünün gelişimi hakkında bkz. İleri 1975, Önertoy 1984, Külahlı̆ğlu İslam 2006, Doğan 2013.

3 Örnek'in öykülerinde mekân algısı için bkz. Erdal, 2015.

4 Toplumsal cinsiyet rolleri bağlamında yazınsal metin incelemelerine örnek olarak bkz. Adak 2017, Değe 2018, Oktay 2018.

5 Sedat Veyis Örnek'in Pirinçler Yeşerecek adlı oyunu da benzer bir konuyu ele almaktadır. Bu oyunda, hayatlarını devam ettirebilmek için Amerikalı askerlerle beraber olmak zorunda kalan bir Koreli kadının yaşamı anlatılmaktadır. Oyundaki sahnelerden birinde tıpkı Yelpaze'de olduğu gibi hayat kadınının çocuğu bir hastalık geçirmektedir. Pirinçler Yeşerecek adlı oyunda kadın kimliğinin temsili üzerine Eunkyung Oh bir yazı kaleme almıştır (2015).

6 Sedat Veyis Örnek'le ilgili anılarını, yazarla gerçekleştirdiği sohbetlerle birlikte aktardığı "Bir Ağabeyi Anarken: Sedat Veyis Örnek” başlıklı yazısında Fuat Bozkurt, Örnek’le Pirinçler Yeşerecek üzerine yaptıkları bir konuşmada "Fuat, bu doğal bir durum, burada da birlikte olduğun kızı pastaneye, birahaneye götürüp bir şeyler 1smarlıyorsun. Orada ise açlık içindeki insanlar kendilerini savunan askerlerle bu tür bir ilişkiyi olağan sayıyordu" diye açıklamada bulunmuştu.” (2015: 79) cümlelerine yer vererek savaş ortamındaki kadının bedenini satmaya mecbur kalışı ve bu durumu olağanlaştırmalarını aktarmıştır. Bu cümleler, Yelpaze adlı öyküde ele alınan kadın kimliğinin temellerini okuma açısından da aydınlatıcı niteliktedir. Yine aynı yazıda Bozkurt, Örnek'in "Batı'ya giden Türk gençlerinin oranın yemeğini tadar gibi kadınlarını da tattı̆̆ı” (2015: 86) değerlendirmesine yer vermiştir. Bu değerlendirmede yine yazarın Almanya'da geçen öykülerindeki eril bakışın kadını bir arzu nesnesi olarak görüp geçiştirmesinin nedenini göstermektedir.

\section{Kaynaklar}

Adak, H. (2011). Otobiyografik benliğin çok-karakterliliği: Halide Edib'in ilk romanlarında toplumsal cinsiyet. Kadınlar Dile Düşünce. İstanbul: İletişim.

Arseven, T. (2015). Sedat Veyis Örnek'in öykücülüğü. folklor/edebiyat. XXI, S. 82, ss. 349-367.

Aygün Cengiz, S., Bulut, M. ve Bayraktutan, G. (2017). Valizde kalanlar Sedat Veyis Örnek'in izleri. Ankara: Ankara Üniversitesi.

Bozkurt, F. (2015). Bir ağabeyi anarken: Sedat Veyis Örnek, folklor/edebiyat. XXI, S. 82, ss. 75-92.

Değe, E. (2018). Cumhuriyet dönemi Türk tiyatrosunda toplumsal cinsiyet (1960-1980). (Yayımlanmamış Yüksek Lisans Tezi). Hacettepe Üniversitesi, Ankara. 
Doğan, A. (2013). 1940-1960 arası Türk hikâye ve romanı. Türk edebiyatı tarihine bir bakış. Ankara: Kurgan Edebiyat.

Erdal, T. (2015). Sedat Veyis Örnek'in öykülerinde "mekân” algısı. folklor/edebiyat. (XXI cilt). S. 82, ss. $377-392$.

İleri, S. (1975). Türk öykücülüğünün genel çizgileri. Türk Dili Dil ve Edebiyat Dergisi. S. 286, ss. 2-29.

Külahlıoğlu İslam, A. (2006). Öykü: 1920-1960. Türk Edebiyatı Tarihi. (IV. cilt) İstanbul: Kültür ve Turizm Bakanlığı.

Oh, E . (2015). Kore savaşı edebiyatı bağlamında Sedat Veyis Örnek'in pirinçler yeşerecek oyununda savaş algısı ve kadınlar. folklor/edebiyat. (XXI. cilt). S. 82, ss. 319-333.

Oktay, G. (2018). Türk romanında kadın ve toplumsal cinsiyet: Kimlik, sınıf, temsil (kadın yazarlar örneğinde 1877-1938). (Yayımlanmamış Doktora Tezi). Çanakkale 18 Mart Üniversitesi, Çanakkale.

Önertoy, O. (1984). Cumhuriyet dönemi Türk romanı ve öyküsü. Ankara: Türkiye İş Bankası Kültür.

[Örnek], S. V. (1949). Bir kadın istiyorum. Sivas Hakikat Gazetesi. 19 May1s 1949. S. 80, ss. 3.

Örnek, S. V. (2015). Ac1 bal. folklor/edebiyat. (XXI. cilt), S. 82, ss. 662.

Örnek, S.V. (2015). Bir kahpeden ne beklenir. folklor/edebiyat. (XXI.cilt), S. 82, ss. 629-630.

Örnek, S.V. (2015). Bir şehirden üç kişi. folklorledebiyat. (XXI. cilt), S. 82, ss. 658-659.

Örnek, S.V. (2015). Cam önünde. folklor/edebiyat. (XXI. cilt). S. 82, ss. 663-664.

Örnek, S.V. (2015). Gece yarısından sonra. folklor/edebiyat. (XXI. cilt). S. 82, ss. 633.

Örnek, S.V. (2015). Günahkârlara dair. folklor/edebiyat. (XXI. cilt). S. 82, ss. 634.

Örnek, S.V. (2015). İlonka, saat dördü bilir misin?. folklor/edebiyat. (XXI. cilt). S. 82, ss. 640.

Örnek, S.V. (2015). İlonka'ya mektup. folklor/edebiyat. (XXI. cilt). S. 82,ss. 665-666.

Örnek, S.V. (2015). İlonka. folklor/edebiyat. (XXI. cilt). S. 82,ss. 635-636.

Örnek, S.V. (2015). Köpekli kadın. folklor/edebiyat. (XXI. cilt). S. 82, ss. 678-682.

Örnek, S.V. (2015). Kuzey-güney. folklor/edebiyat. (XXI. cilt). S. 82, ss. 660-661.

Örnek, S.V. (2015). Mezarlıktan bir kaçış. folklor/edebiyat. (XXI. cilt). S.82, ss. 637.

Örnek, S.V. (2015). Park. folklor/edebiyat. (XXI. cilt). S. 82,ss. 638-639.

Örnek, S.V. (2015). Sabah. folklor/edebiyat. (XXI. cilt). S. 82, ss. 667-668.

Örnek, S.V. (2015). Suda oynar balıklar. folklor/edebiyat. (XXI. cilt). S. 82, ss. 669-671.

Örnek, S.V. (2015). Tabut. folklor/edebiyat. (XXI. cilt). S. 82, ss. 686-687.

Örnek, S.V. (2015). Yelpaze. folklor/edebiyat. (XXI. cilt). S. 82, ss. 641-644. 